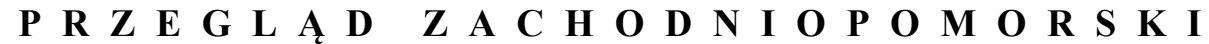 ROCZNIK XXXV (LXIV) ROK 2020 ZESZYT 3
}

\section{$\begin{array}{lllllllll}\mathbf{A} & \mathbf{R} & \mathbf{T} & \mathbf{Y} & \mathbf{K} & \mathbf{U} & \mathbf{L} & \mathbf{Y}\end{array}$}

\author{
ADRIANNA JAKÓBCZYK \\ https://orcid.org/0000-0001-6362-5954 \\ Uniwersytet Warszawski \\ e-mail: a.jakobczyk@uw.edu.pl
}

\section{WyOBCOWANIE TERYTORIALNE NA POMORZU ZACHODNIM. O HOMUNCULUSIE Z TRYPTYKU BRITTY WUTTKE NA TLE PORÓWNAWCZYM}

Słowa kluczowe: Wuttke, Lachmann, Niemcy, Międzyzdroje, wysiedlenia, Obcy, przestrzeń, palimpsestowość

Keywords: Wuttke, Lachmann, German, Międzyzdroje, displacement, Other, space, palimpsestness

Britta Wuttke nie jest autorką powszechnie znaną, osiągnęła popularność jedynie lokalną, a jej unikalne doświadczenia istotnie wpłynęły na Homunculusa $z$ tryptyku - powieść będącą punktem wyjścia dla niniejszego artykułu. Dlatego pozwolę sobie zarysować krótko biografię pisarki. Urodziła się w 1940 roku w Międzyzdrojach w niemieckiej rodzinie. W lutym 1945 roku wraz z matką została ewakuowana z Polski do Meklemburgii, lecz na początku czerwca tego samego roku postanowiły wrócić „,do domu, czyli do Międzyzdrojów” mieszkali jej krewni ze strony matki. Wuttke ukończyła polską szkołę, a następnie studia medyczne w Szczecinie. Osiągnęła pełną dwujęzyczność.

1 Agata Rokicka, Moje „w domu” jest tutaj, RadioSzczecin.pl, dostęp 16.07.2019, http://radioszczecin.pl/245,496,27122015-moje-w-domu-jest-tutaj; Krystyna Krajcewicz, Dwie ojczyzny Britty Wuttke, PolskieRadio.pl, dostęp 16.07.2019, http://www.polskieradio.pl/80/4198/Artykul/1322288,Dwie-ojczyzny-Britty-Wuttke. 
W 1975 roku wzięła udział w ogłoszonym z okazji trzydziestolecia Pomorza Zachodniego konkursie na powieść lub tom opowiadań związany tematycznie z tym właśnie obszarem - jej Homunculusa z tryptyku uhonorowano drugą nagrodą. Książka doczekała się dwóch wydań (w 1977 oraz 1980 r.), została dobrze przyjęta przez krytykę i otrzymała wyróżnienia - m.in. Nagrodę Artystyczną Młodych „Głosu Szczecińskiego” oraz nagrodę „Spojrzeń” za najlepszy debiut literacki. To jedyna powieść w dorobku pisarki², która publikowała później również opowiadania, reportaże, eseje, słuchowiska radiowe oraz przekłady, jednak poświęciła się głównie karierze lekarskiej. Po ogłoszeniu w Polsce stanu wojennego została w Berlinie, gdzie mieszka do dziś3.

Homunculus $z$ tryptyku został opatrzony odautorskim komentarzem: „Wszystkie opisane tu postacie są wymyślone i ewentualne ich podobieństwo do jakichkolwiek osób żyjących bądź zmarłych może być tylko przypadkiem”4. Jednakże nietrudno zauważyć w powieści inspiracje autobiograficzne. W wywiadach Britta Wuttke przytacza jako anegdoty ze swojego życia te same sceny, które opisała w powieści. Nigdzie nie zostaje podane, jak nazywa się główna bohaterka utworu, lecz pojawiają się sugestie, że jej personalia są tożsame z imieniem i nazwiskiem autorki ${ }^{5}$. Relacjonując te uwarunkowania, nie sugeruję bynajmniej, że Homunculusa z tryptyku należy czytać jak literaturę dokumentu osobistego. Wydarzenia z życia autorki zostały z pewnością sfabularyzowane, a ich pamięć wtórnie utrwalona poprzez powieściowy zapis. Nie zmienia to jednak

2 Istnieją przekazy, że rękopisy kolejnych powieści spłonęły w pożarze rodzinnego domu Britty Wuttke w Międzyzdrojach, zob. Tatiana Czerska, „Granice w pamięci. Pisarstwo autobiograficzne kobiet jako forma dyskursu neokolonialnego”, w: Historie, spoleczeństwa, przestrzenie dialogu. Studia postzależnościowe w perspektywie porównawczej, red. Hanna Gosk, Dorota Kołodziejczyk (Kraków: Universitas, 2014), 424; Bogdan Twardochleb, Nastały czasy zupetnie genialne... Opowieść o Międzyzdrojach z Britta Wuttke w roli głównej, TransodraOnline.net, dostęp 25.07.2019, http://www.transodra-online.net/pl/node/8095.

3 Okoliczności swojego wyjazdu do Niemiec Britta Wuttke podsumowała w mailu do mnie: „W Berlinie wylądowałam wbrew mej woli - pojechałam do wujka na leczenie akupunkturą, nad Polską zawieszono stan wojenny, a 19 lutego 1982 roku palił się nasz dom, który po pożarze, mokrusieńki niby gąbka wodą nasączona, nie nadawał się do mieszkania, więc ściągnęłam córkę i rodziców, no i zostałam tu" (e-mail z 3 września 2019 roku, ten i kolejne fragmenty korespondencji publikuję za zgodą autorki).

${ }^{4}$ Britta Wuttke, Homunculus z tryptyku (Poznań: Wydawnictwo Poznańskie, 1980), 5. W dalszej części artykułu cytaty będę lokalizować w tekście, podając w nawiasie skrót HZT i numer strony.

5 Przykładem mogą być stwierdzenia "Nasze nazwisko zawiera dwie takie same spółgłoski” (HZT, s. 74) oraz „Chciały dać mi imię Brygida, zawierające ten sam rdzeń, co dotychczasowe” (HZT, s. 75). 
tego, że Britta Wuttke życie na polsko-niemieckim pograniczu znała z autopsji i czerpanie $\mathrm{z}$ tych przeżyć $\mathrm{w}$ procesie twórczym trzeba uznać za znaczące.

Narratorką Homunculusa z tryptyku jest mieszkająca w Międzyzdrojach Niemka - przedstawione zostały jej losy od dzieciństwa aż po zdobycie zawodu, macierzyństwo i drugi rozwód. Jeden z głównych wątków książki to pochodzenie bohaterki, jej poczucie inności, niemożność pogodzenia się z przeszłością swojego narodu, wrastanie w polską społeczność i konflikty z tym związane zwłaszcza z bliższą i dalszą rodziną. Narracja w powieści jest pierwszoosobowa, perspektywa bohaterki-narratorki - początkowo naiwna - zmienia się wraz z kolejnymi etapami jej życia.

W niniejszym artykule będę się również odnosić do eseju „Wypędzenie” po polsku. Jego autorem jest Peter/Piotr Lachmann, który urodził się w 1935 roku w Gliwicach i pozostał tam po wojnie z matką i siostrą, zatem dorastał w podobnych okolicznościach co Britta Wuttke. Wywołane z pamięci - jego zbiór esejów problematyzujący między innymi te doświadczenia - został napisany z dużej perspektywy czasowej, opublikowany w 1999 roku, a więc w zupełnie innych realiach politycznych niż powieść Wuttke. Dlatego uważam utwór Lachmanna za szczególnie wartościowy kontekst dla Homunculusa z tryptyku. Nie ulega wątpliwości zbieżność doświadczeń obojga autorów, mimo że mieszkali na dwóch różnych (choć wchodzących w skład tzw. Ziem Odzyskanych) obszarach - Pomorzu Zachodnim i Śląsku.

\section{Wyobcowanie terytorialne}

„Berta powiedziała mi [...] że zostałyście w domu i jesteście w Polsce” (HZT, s. 79) - pisze po wojnie ojciec bohaterki do przebywających w Międzyzdrojach żony i córki. Sytuacja przedstawiona w Homunculusie z tryptyku bardzo dobrze ukazuje, jak błędne bywa postrzeganie mniejszości narodowych jako migrantów, przybyszów skądś. Trafnie odnosi się do tego zagadnienia Helena Duć-Fajfer: „[...] większość społeczności mniejszościowych znikąd do Polski nie przyszła, tylko, gdy kształtowała się w politycznych granicach terytorialnych państwowość polska, obejmowała ona swym zasięgiem szereg wspólnot etnicznych zamieszkujących dane (uznawane i symbolizowane jako swoje) terytoria”. Tak właśnie wy-

${ }^{6}$ Helena Duć-Fajfer, ,„»Jestem u siebie « - tekstualna opozycja przeciw symbolicznemu wykorzenieniu wpisana w dyskurs mniejszościowy w Polsce”, w: Historie, społeczeństwa, przestrzenie dialogu. Studia postzależnościowe w perspektywie porównawczej, red. Hanna Gosk, Dorota Kołodziejczyk (Kraków: Universitas, 2014), 450. 
glądała specyficzna sytuacja Niemców pozostałych po wojnie na tzw. Ziemiach Odzyskanych. Oni byli u siebie, to ziemia ojczysta usunęła się im spod stóp. Jak pisała w korespondencji ze mną Britta Wuttke: „Dziewiątego października 1945 roku poszłyśmy spać - Babcia, Mama, dwie ciocie i ja - a dziesiątego października obudziłyśmy się za granicą. Bez paszportów i wiz i we własnych łóżkach. Cud, który nie mieścił się w głowach dorosłych"”.

W języku niemieckim istnieją dwa pojęcia, które mogą być pomocne przy opisie sytuacji Niemców pozostałych po wojnie na terenie Polski - Heimat i Vaterland. Heimat to słowo emocjonalnie nacechowane, oznacza strony/miasto rodzinne, miejsce, gdzie ktoś się urodził, wychował i „czuje się jak w domu”» (stąd komponent „Heim” - 'dom' w znaczeniu rodzina, ognisko domowe). Słowo Vaterland łatwiej wytłumaczyć, ponieważ istnieje dla niego prosty polski odpowiednik 'ojczyzna'. To kraj rozumiany jako miejsce zamieszkiwania narodu. Wysiedlenie czy wyjazd do Niemiec na własną rękę wymuszały opuszczenie Heimat, domu i rodzinnej miejscowości; dokonywała się więc utrata zakorzenienia na poziomie lokalnym. Z kolei pozostanie tam, gdzie wszystko bliskie i znane, automatycznie oznaczało opuszczenie Vaterland, ojczyzny, zamieszkiwanie na terytorium obcego państwa, zazwyczaj bez znajomości języka, często wśród osób, które po doświadczeniach drugiej wojny światowej odnosiły się do Niemców wrogo9.

Zaznaczyć należy, że pozostanie na tzw. Ziemiach Odzyskanych nie zawsze było koniecznością czy głęboko przemyślaną decyzją. Narrator eseju Lachman$\mathrm{na}^{10}$ relacjonuje, że jego rodzina została po wojnie w Polsce, ponieważ początkowo matka ,przegapiła moment najbardziej odpowiedni do wyjazdu, ucieczki, przeprowadzki, jakbyśmy tego nie nazwali"11, a następnie - gdy byli już gotowi, by opuścić Gliwice - on sam miał wypadek i dotkliwie poraniony nie mógł odbyć planowanej podróży. Z kolei narratorka powieści Wuttke powody pozostania

7 E-mail z 10 września 2019 roku.

8 Zob. Heimat, Duden.de, dostęp 5.09.2019, https://www.duden.de/rechtschreibung/Heimat.

9 Jak stwierdziła Małgorzata Ruchniewicz: „Ludność polska ogólnie akceptowała masowe wysiedlenia Niemców, widząc w nich karę za krzywdy wojenne oraz umocnienie władania państwa polskiego i ich samych poniemieckimi nieruchomościami i dobytkiem" (Małgorzata Ruchniewicz, „Niemcy”, w: Wysiedlenia, wypędzenia i ucieczki 1939-1959. Atlas ziem Polski, red. Witold Sienkiewicz, Grzegorz Hryciuk [Warszawa: Demart, 2008], 191).

${ }^{10}$ Nie utożsamiam ,ja” mówiącego eseju z Piotrem Lachmannem.

${ }^{11}$ Piotr Lachmann, „»Wypędzenie« po polsku”, w: tegoż, Wywołane z pamięci (Olsztyn: Wspólnota Kulturowa „Borussia”, 1999), 29. W dalszej części artykułu cytaty będę lokalizować w tekście, podając w nawiasie skrót WPP i numer strony. 
w Międzyzdrojach przedstawia częściowo w mowie pozornie zależnej: „Zostałyśmy tu, by ojciec do nas trafił, no i dla Babci, wędrówka zbyt by ją zmęczyła. Wydaje mi się, że mama lubi podejmować decyzje, ale nie lubi ponosić za nie odpowiedzialności” (HZT, s. 43).

Ironiczny komentarz, którym narratorka opatrzyła wypowiedź swojej matki, wskazuje, że w przypadku obu opisywanych rodzin decyzja o wybraniu Heimat, a nie Vaterland, była dość przypadkowa. Jednak zarówno w eseju Lachmanna, jak i powieści Wuttke przedstawiona została sytuacja, w której w danej miejscowości przebywa i po wojnie zostaje większa rodzina - nie tylko matka i dziecko lub dzieci, lecz także babcia i ciocie. Jest to znaczące, ponieważ w obu przypadkach w momencie wysiedlenia część rodziny pozostawała na miejscu i służyła wsparciem tym, którzy powracali. Można się także domyślać, że łatwiej było pozostać w Heimat, gdy najbliższe osoby również tam przebywały, pomagając w opiece nad dziećmi oraz odpędzając groźbę samotności i całkowitej izolacji.

Bohaterowie obu utworów nie mieli również żadnych problemów, by uzyskać polskie obywatelstwo ${ }^{12}$. Piotr Lachmann nazwał to zjawisko „wypędzeniem po polsku", bazując na stereotypie przeciwstawiającym niemieckiemu Ordnung polski bałagan. Lachmann w swoim eseju podkreśla brak starań polskiej administracji, by skutecznie pozbyć się Niemców z terenu Gliwic: „[Polacy] zjawili się w aureoli nowych administratorów. No i tych właśnie, którzy musieli wykonać przykre zadanie »wypędzania« pozostałych w mieście Niemców. Nigdy nie zwierzałem się nikomu z wczesnego dziwnego wrażenia, że mam do czynienia z czymś upozorowanym. [...] [Polacy u]dawali więc jakby nowych Niemców-urzędników, wprowadzając jakieś biurokratyczne reguły gry, do której musieliśmy »robić dobre miny«. Bo nie była to przyjemna gra dla uczestniczących w niej Niemców. Ale grali, jak powiadam, również Polacy. [...] ja odbierałem to wszystko jako zabawę w tzw. »wypędzenie«" (WPP, s. 30) ${ }^{13}$.

${ }^{12} \mathrm{~W}$ Homunculusie z tryptyku przytoczony zostaje - jak można się domyślać - fragment ze skierowanego do Niemców oficjalnego dokumentu: ,»Jeśli ktoś ma zamiar pozostać, winien przyjąć obywatelstwo... - steht angeschrieben" (HZT, s. 38). Odnosi się to do czasów tuż po wojnie. Gdy w 1950 r. do rodziny chce dołączyć ojciec głównej bohaterki, sprowadzenie go do Międzyzdrojów wymaga już wyprawy do Świnoujścia i uruchomienia znajomości. Jednak koniec końców i to się udaje. Z kolei w „Wypędzeniu” po polsku pojawia się wzmianka o tym, że „nieznająca w ogóle polskiego i ewidentnie z niemieckiej (albo i austriackiej) gliny ulepiona matka" (WPP, s. 33) narratora bez trudu uzyskała zaświadczenie, że jest narodowości polskiej.

${ }^{13}$ Narrator eseju Lachmanna opisuje również, jak jego matka wyszła z dwojgiem dzieci z obozu zbiorczego dla Niemców, zatrzymała się u nadal przebywającej w Gliwicach rodziny (która 
Z kolei w Homunculusie z tryptyku wysiedlenie właściwie nie zostaje sproblematyzowane. Narratorka wspomina, że ewakuowano ją razem z matką do Meklemburgii, a następnie opisuje ich powrót do Międzyzdrojów - pociągiem do Rostocku, a dalej już pieszo. Uwagę zwraca przy tym, że dwukrotnie pojawia się neutralne słowo „ewakuacja” (HZT, s. 59, 94), jednokrotnie „przesiedlanie” (HZT, s. 38), a nigdzie nie pada nacechowane „wypędzenie” jak u Lachmanna (choć użyte w ironicznym kontekście, gdyż narrator eseju jednoznacznie dystansuje się od poglądów - jak ich nazywa - „klasycznych wypędzonych”). Warto dodać, że we współczesnej polskiej historiografii zazwyczaj używa się w tym kontekście określenia „przymusowe wysiedlenia”"14. O ile Lachmann opisuje rolę Polaków w tym procesie, o tyle w powieści Wuttke „ewakuacja” została przedstawiona jak katastrofa naturalna, jakby nie stali za nią żadni ludzie. Na rolę Polaków zostaje opuszczona zasłona milczenia, obawę budzą natomiast spotykani w drodze powrotnej z Meklemburgii Rosjanie.

Ta rozbieżność w prowadzeniu narracji jest symptomem głębszych różnic. W eseju Lachmanna wysiedlenie Niemców i nastanie polskiej administracji to teatr niekonsekwencji, podobnie przedzierzganie się w „Polaków nowicjuszy (nuworyszy?)" (WPP, s. 32). Ostrze ironii wymierzone jest zarówno w Niemców, jak i Polaków. Tymczasem bohaterka powieści Wuttke w żaden sposób nie kwestionuje działań polskiej administracji, a także jest zupełnie bezbronna wobec polskiej narracji o Niemcach, z którą styka się w szkole czy w prasie dziecięcej. $\mathrm{W}$ procesie socjalizacji do polskości uwewnętrznia polską perspektywę - i to w wydaniu propagandowym. W wyniku tego procesu rozwija silny wstyd i poczucie winy ${ }^{15}$ związane ze swoim niemieckim pochodzeniem.

mogła zostać w mieście ze względów praktycznych - potrzeba było pracowników dla sądu i więzienia), po czym nikt nigdy ich z tego powodu nie szukał i nie robił im problemów.

${ }^{14}$ Przykładowo, historyk Kazimierz Kozłowski relacjonuje: „Chcę podkreślić, że niemal pełna wymiana ludności Międzyzdrojów nastąpiła w latach 1945-1948 i że miejsce wysiedlonych przymusowo Niemców, oczywiście poza tymi, którzy wcześniej uciekli przed nadchodzącym frontem, zajęli Polacy” (Kazimierz Kozłowski, „Dlaczego Międzyzdroje, a nie Misdroy. Geneza i istota przemian politycznych i ludnościowych po drugiej wojnie światowej”, w: Słoneczne Międzyzdroje. Historia i przyroda, cz. 1, red. Kazimierz Kozłowski, Bogdan Jakuczun [Międzyzdroje: Oficyna Wydawnicza Archiwum Państwowego „Dokument”, 2015], 15).

${ }^{15}$ Bohaterka Homunculusa z tryptyku referuje: „Skądś, z głębi bezustannie wychyla się wstyd” (HZT, s. 108); „Ciocie piją coraz częściej i więcej. [...] Wstyd mi za nie - i o dziwo! - nie dlatego, że są moimi ciociami, lecz dlatego, że przygodnie słyszę: »Niemki, psiekrwie, a tak u nich brudno«. Nie mam w ogóle, i to żadnego, poczucia niemieckości, a mimo to wzdrygam się, słysząc podobne opinie. Wstydzę się na filmach, w których Niemcy są groteskowi i śmieszni” (HZT, s. 103). Jednak w relacji narratorki jeszcze więcej niż wstydu jest poczucia winy. Wielokrotnie powracają 
Sądzę, że narrator Lachmanna - w przeciwieństwie do narratorki Wuttke nie przyjął całkowicie polskiego punktu widzenia, ponieważ zdążył zadomowić się w niemieckiej rzeczywistości i gdy nastała nowa administracja, dokładnie wiedział, co stracił, miał porównanie ${ }^{16}$. Tymczasem pierwsze wspomnienia bohaterki Homunculusa z tryptyku formują się już po wojnie. Dziewczynka stwierdza: „Nie pamiętam prawie nic sprzed ewakuacji; to, co sobie przypominam, jest mgliste i jakby nie moje" (HZT, s. 59). Stałe rozdarcie i starania, by dopasować się do polskiej większości, były dla niej sytuacją zastaną. Nie miała szansy przekonać się, jak to jest żyć bez ciągłego aspirowania, bez doświadczania dyskryminacji i Othering.

Nie wolno również zapomnieć, że powieść Wuttke ukazała się w zupełnie innych realiach politycznych niż utwór Lachmanna. ,Wypędzenie” po polsku to niewątpliwie utwór przenikliwy, lecz sposób jego sformułowania wyraźnie uwidacznia, że w tekście dochodzi do przełamania tabu i poruszenia tematów, które nie były dotąd obecne $\mathrm{w}$ dyskursie publicznym ${ }^{17}$. Mowa przy tym o eseju - a więc

rozważania, kim by była, gdyby urodziła się trzydzieści lat wcześniej lub rozstrzygnięcia wojenne okazały się inne: „Uzyskałam wolność, własną, indywidualną, ale nie pozbędę się poczucia odpowiedzialności wynikającego z przeszłości, ze świadomości tego, czym ja bym była, gdybyśmy wtedy nie pozostali lub gdyby oni wygrali wojnę, i będącej chyba również skutkiem zbyt głębokiej znajomości natury przedmiotu" (HZT, s. 136; zob. też HZT, s. 108-109, 138, 170, 210).

${ }^{16}$ Trudno w tym kontekście nie uwzględnić również odmiennych doświadczeń autorów, ponieważ oba analizowane utwory mają charakter autobiograficzny. W wyniku ,wypędzenia po polsku" Lachmann doświadczył wielu zmian i strat - wydaje się, że więcej niż Wuttke. Po nastaniu polskiej administracji został ponownie ochrzczony i do teraz funkcjonuje zarówno jako Peter, jak i Piotr - jego tożsamość została zatem również nominalnie rozdwojona. Jeśli wierzyć narracji eseistycznej, Lachmannowie po wojnie musieli się przeprowadzić z powodu przejęcia ich mieszkania przez polską administrację, doświadczyli również „deklasacj[i] i degradacj[i], bo ze średnio zamożnej zamieniliśmy się w ocierającą się o biedę zdziesiątkowaną rodzinę [...]” (WPP, s. 38). Bardzo istotny wpływ na Lachmanna musiała mieć również śmierć jego ojca w czasie wojny (choć nie miało to bezpośredniego związku z ,wypędzeniem po polsku”). Tymczasem ojciec Wuttke wrócił do rodziny w roku 1950, a jeśli ufać narracji powieściowej, jej rodzina po wojnie bez przeszkód mieszkała w swoim dawnym domu i mimo pogorszenia warunków, doświadczała względnie stabilnej sytuacji materialnej.

${ }^{17} \mathrm{~W}$,,Wypędzeniu” po polsku eseista próbuje wypowiedzieć doświadczenia wyobcowania terytorialnego i wypędzenia wewnętrznego, które były dla niego fundujące. Robi to jednak w bardzo specyficzny sposób. Referuje je w narracji autoironicznej, sięga po niefortunną - perswazyjną, a nie analityczną - analogię do gwałtu i każdorazowo zestawia je asekuracyjnie $\mathrm{z}$ doświadczeniami innych grup narodowościowych. Jak sądzę, przyczyny tego stanu rzeczy są dwie. Po pierwsze, Lachmann stara się wyrazić coś, co w momencie wydania jego esejów nie funkcjonowało ani w debacie publicznej, ani w utworach literackich - do teraz funkcjonuje wyłącznie marginalnie. Dla jego doświadczenia brakuje więc wzorów opowiadalności (to określenie sformułowane przez Hannę Gosk). Po drugie, Lachmann usiłuje snuć swoją narrację, cały czas uwzględniając dwie inne, dużo bardziej rozpowszechnione i ugruntowane opowieści o tych czasach - opowieść 
gatunku szczególnie predestynowanym do metarefleksji - który został wydany ponad dwadzieścia lat później niż powieść Wuttke. Skoro nawet Lachmannowi było trudno upublicznić inne spojrzenie na sytuację Niemców pozostałych po wojnie na terenie Polski, w jaki sposób miałaby to zrobić Britta Wuttke, która pisała swoją powieść w latach 70.? Nie mówiąc o tym, że gdyby autorka takiego przełamania tabu dokonała, jej książka nigdy nie zostałaby dopuszczona do druku $^{18}$.

Dla Niemców przedstawionych w obu utworach literackich pozostanie w rodzinnej miejscowości, a tym samym w Polsce, nie nastręczało szczególnych trudności pod względem administracyjnym, lecz konsekwencje tej decyzji były znaczące i często dotkliwe. Polacy postrzegali ich bowiem jako obcych, kogoś z zewnątrz. Ludność, która pojawiła się na tych terenach po wojnie, to polscy przesiedleńcy. Jak stwierdził Kazimierz Kozłowski w odniesieniu do Międzyzdrojów: „Przestrzeń miasta [...] wypełnili Polacy, pochodzący w 2/3 z Polski centralnej i południowej, a w 1/3 z terenów II RP utraconych na wschodzie, przy pewnym odsetku autochtonów, reemigrantów i mniejszości narodowych"19. Swoistym paradoksem jest zatem to, że Niemcy znaleźli się wówczas w pozycji obcych, mimo że zamieszkiwali Międzyzdroje niejednokrotnie od pokoleń.

Mamy tu więc do czynienia $\mathrm{z}$ sytuacją, gdy podmiot mieszka w swojej miejscowości, częstokroć w tym samym domu czy mieszkaniu, chodzi tymi samymi ulicami, bywa w tych samych budynkach, lecz w jego otoczeniu zmienia się wszystko - administracja, ludność, dominująca narodowość i religia, język urzędowy, nazewnictwo ulic i obiektów architektonicznych, kultura i obyczaje. Ta zmiana nie zostaje wywołana czy zaaranżowana przez doświadczającą jej osobę, lecz przychodzi z zewnątrz. To z punktu widzenia podmiotu wręcz

o ofiarach zbrodni hitlerowskich, do której podchodzi z dużym szacunkiem, oraz opowieść Niemców wysiedlonych (wypędzonych) z terenów Polski, od której się odżegnuje. Autor jest bardzo świadomy swojego położenia, wie, jak łatwo byłoby mu przypisać lekceważenie pierwszej z tych opowieści bądź sympatyzowanie z drugą.

${ }^{18}$ Według relacji Britty Wuttke ingerencje cenzury w Homunculusa z tryptyku były nieznaczne i nie dotyczyły przedstawienia Niemców, Niemiec czy sytuacji mniejszości niemieckiej na tzw. Ziemiach Odzyskanych. Jednakże rozdanie ról powieściowych z całą pewnością odpowiadało interesom ówczesnej władzy. Oznaczałoby to, że autorka sama stworzyła powieść w kształcie idealnie dopasowanym do oczekiwań wysuwanych w latach 50.-70. wobec powieści migracyjnej. Mógł to być wynik zawierzenia propagandzie PRL i przyjęcia ściśle ograniczonych ram myślenia o świecie, a nawet własnym doświadczeniu, lub też autocenzury, uprzedzającej potencjalne zewnętrzne ingerencje. Ponieważ dotykam tutaj motywacji autorskiej, nigdy nie będę w stanie sformułować na ten temat wiążących wniosków.

${ }^{19}$ Kozłowski, „Dlaczego”, 16. 
surrealistyczne zjawisko proponuję nazwać wyobcowaniem terytorialnym. Podkreślić należy, że dotyczy ono zarówno młodszego, jak i starszego pokolenia pozostałego na rodzimej ziemi po zmianach administracyjnych - lecz w zasadniczo odmienny sposób.

Inaczej funkcjonować będą bowiem dorośli, mający klarowne wspomnienia realiów i przestrzeni zanim nastąpiło wyobcowanie terytorialne, a inaczej dzieci, które w nowo ukształtowanej rzeczywistości dorastały. Błędem byłoby jednak myślenie, że młodsze pokolenie - ze względu na bilingwizm i dużą swobodę poruszania się między dwiema kulturami - nie odczuje wyobcowania terytorialnego. Na sytuację dzieci istotnie wpływały nierzadko pogorszenie sytuacji materialnej rodziny oraz parentyfikacja - przejęcie nieadekwatnej do wieku odpowiedzialności za nieznających języka rodziców. Wpływ na sposób funkcjonowania i świat wyobrażeń młodszego pokolenia miały również przynależność do mniejszości etnicznej i kulturowej, doświadczanie dyskryminacji bądź niechęci ze strony grupy większościowej, wychowanie przez rodziców żywo pamiętających wcześniejsze czasy oraz obecność artefaktów będących ich świadectwem.

Pozwolę sobie przytoczyć fragment $\mathrm{z}$,Wypędzenia" po polsku, który dobrze ilustruje tę sytuację oraz odczucia doświadczającego jej podmiotu: „Ja straciłem Heimat inaczej [niż wysiedleni Niemcy - dop. A.J.] i musiałem uczestniczyć z początku jako niemy (niemiecki) świadek - w jej przeistaczaniu się z (kresowej) niemieckiej w polską (znowu kresową, ale głównie dzięki autentycznym uchodźcom z Kresów) prowincję. Chodziłem dalej, jako połowicznie »wypędzony«, po swojej starej Heimat (wszak bez sentymentów lokalnego patrioty), chodziłem jako ten sam i już nie ten sam. Kulisy były identyczne, ale aktorzy inni i również z wolna zmieniała się ogólna aura, genius loci jednego i tego samego miejsca. Czy było ono jeszcze »tożsame« ze sobą? Czy ja byłem »jeszcze« tożsamy ze sobą? [...] W mojej pamięci i moim przeżywaniu tego miejsca stale współistniały te dwie aury, dwie wizje pozornie identycznej przestrzeni, którą czas zmasakrował i wypaczył [...]" (WPP, s. 38).

Najważniejsze zjawiska, których doświadcza bohater wyobcowany terytorialnie, to funkcjonowanie w odniesieniu do dwóch języków i kultur, znalezienie się w pozycji obcego wobec grupy dominującej oraz palimpsestowość przestrzeni. Ze względu na ograniczone ramy niniejszego artykułu przyjrzę się bliżej tylko trzeciemu z tych zjawisk, moim zdaniem najciekawszemu. 


\section{Palimpsestowość przestrzeni}

Po drugiej wojnie światowej Misdroy zostało przemianowane na Międzyzdroje, nazwy ulic i budynków również uległy polonizacji lub zupełnej zmianie - miejscowość była stopniowo adaptowana jako miejsce do życia ludności polskiej. Jednak wprowadzenie nowego nazewnictwa nie ma funkcji wyłącznie praktycznej, jest także sygnałem praw do danego terytorium, jego własności. Ten, kto nazywa, używając swojego języka, przywołując swoją historię i bohaterów, ukazuje władzę i dominację kulturową. Jak stwierdziła Helena Duć-Fajfer: „Ojczyzny wypędzonych poddawane są destrukcji, strategicznemu wydrążaniu miejsc z pamięci w celu ich »rekultywacji«, czyli uzyskania efektu powtórnej czy nowej swojskości miejsc, zdominowanych i zawłaszczonych przez inne dyskursy. Poszczególne wspólnoty zawłaszczają przestrzeń, budując pomniki, stawiając obeliski czy nadając odpowiednie nazwy ulicom, skwerom lub miejscom. Sprawowanie symbolicznej władzy nad miejscem legitymizuje wspólnotę, ale też wyklucza z tej przestrzeni inne, konkurencyjne grupy" 20 .

Nowo przybyli mieszkańcy danej miejscowości przyjmują powojenną nomenklaturę jak coś oczywistego, lecz autochtoni są świadkami nadpisywania, przykrywania nowym nazewnictwem dawnych nazw ulic i budynków. Nie musi to być oczywisty proces, jeśli dana miejscowość uległa znacznemu zniszczeniu w czasie wojny - wówczas zmienia się też topografia, więc i nowa nomenklatura może być odpowiednia. Lecz w wypadku miejscowości w znacznej mierze ocalałych - a taką były Międzyzdroje ${ }^{21}$ - mówienie o palimpsestowości przestrzeni wydaje się adekwatne. Przestrzeń pozostała zatem w znacznej mierze taka sama, a zmiany dokonały się na poziomie „meta”, na płaszczyźnie opisu - zatarto dawne nazwy ulic i obiektów architektonicznych i nadano im nowe. Dokładnie jak w przypadku palimpsestu ${ }^{22}$.

${ }^{20}$ Duć-Fajfer, ,Jestem”, 462. Badaczka wspiera te rozpoznania na pracy redaktorów tomu Społeczne tworzenie miejsc. Globalizacja, etniczność, władza, red. Andrzej Bukowski, Marcin Lubaś, Jacek Nowak (Kraków: Wydawnictwo Uniwersytetu Jagiellońskiego, 2010).

${ }^{21}$ Małgorzata Gwiazdowska stwierdziła: „Zniszczenia wojenne nie były duże. Spośród 675 budynków istniejących tu w 1939 r., 561 w 1946 r. nadawało się do zamieszkania. Poważnie zniszczona była jedynie linia kolejowa, wskutek czego Międzyzdroje wraz z całą wyspą odcięte były od lądu stałego” (Małgorzata Gwiazdowska, „Historyczna zabudowa międzyzdrojskiego kurortu. Dawniej i dzisiaj...”, w: Słoneczne Międzyzdroje. Historia i przyroda, cz. 1, red. Kazimierz Kozłowski, Bogdan Jakuczun [Międzyzdroje: Oficyna Wydawnicza Archiwum Państwowego „Dokument”, 2015], 59).

${ }^{22}$ Należy zaznaczyć, że metafora palimpsestu jest powszechnie używana w badaniach miejskich (zob. Elżbieta Rybicka, „Pamięć i miasto. Palimpsest vs. pole walki”, Teksty Drugie 5 [2011]: 
Poprzez nową nomenklaturę przestrzeń zostaje oswojona, udomowiona. To ważne, ponieważ Polacy wkroczyli po wojnie do miejscowości niemieckiej ${ }^{23}$, która swoim ukształtowaniem, architekturą i nazewnictwem dobitnie świadczyła o dawnych mieszkańcach, kulturze, języku i religii. By unaocznić, jakie to mogło być odczucie dla nowo przybyłych, przytoczę fragment Hanemanna, który ilustruje to doświadczenie. Narrator relacjonuje wędrówkę swoich pochodzących z Warszawy rodziców po Gdańsku w poszukiwaniu domu: „W śródmieściu, przy dworcowej hali, z której nie zniknęły jeszcze tablice z czarnym napisem »Danzig«, zielone ciężarówki przebijały się przez ośnieżone gruzowisko płosząc stada wron zajętych wydziobywaniem mięsa z zabitych koni [...]. Ulica, którą szli, nazywała się »Kronprinzenallee« - drewniany barak przystanku straszył emaliowaną tabliczką z gotyckim napisem. [...] Teraz zza żelaznego płotu, [...] zza uchylonych bram i furtek z gotycką cyfrą, zza gąszczy bluszczu i nawisów dzikiego wina zaglądali do ogrodów, w których stały małe trójokienne wille, podobne do letnich domków znad Wannsee [...]. Mama, gdy tylko weszła do sieni z sinymi stiukami, cofnęła się szybko, choć sama nie wiedziała dlaczego... Na miedzianej tabliczce obok napisu »Briefe«, połyskiwały pochyłe literki: »Erich Schultz«, »Wolfgang Bierenstein«, »Johann Peltz«"24.

Miasto to materialny nośnik pamięci kulturowej. W miejscowości tak silnie naznaczonej bytnością i kulturą innej grupy zmiany toponimiczne to pierwszy krok w stronę - jak to ujęła w przytoczonym wcześniej cytacie Duć-Fajfer - legitymizacji nowej wspólnoty, ale też wykluczenia innych, potencjalnie konkurencyjnych grup. Po pierwszym manuskrypcie, dawnej toponimii, zawsze jednak pozostaje ślad, napięcie między dwoma systemami - w omawianym przypadku rozgrywa się ono głównie w pamięci autochtonów. Przyjrzyjmy się, jak

202-203), także w kontekście obszarów poniemieckich - zob. m.in. Arkadiusz Bagłajewski, „Miasto-palimpsest”, w: Miejsce rzeczywiste, miejsce wyobrażone. Studia nad kategoria miejsca w przestrzeni kultury, red. Małgorzata Kitowska-Łysiak, Elżbieta Wolicka (Lublin: Towarzystwo Naukowe KUL, 1999).

${ }^{23}$ Jak stwierdził Kazimierz Kozłowski: „Jest sprawą oczywistą, że powojennych losów Międzyzdrojów nie można oderwać od historii polskiej części Pomorza Zachodniego (przed wojną była tu pruska prowincja pomorska w 99\% zamieszkiwana przez Niemców). [...] Miejsce dominujących w okresie niemieckim kościołów protestanckich zajął Kościół katolicki (przed wojną protestantów było ok. $95 \%$, a katolików $4 \%$, po wojnie zaś katolicy stanowili ponad $90 \%$ populacji)" (Kozłowski, „Dlaczego”, 15-16).

${ }^{24}$ Stefan Chwin, Hanemann (Gdańsk: Słowo/obraz terytoria, 1997), 71-74. Mam świadomość historycznych i demograficznych różnic pomiędzy Pomorzem Zachodnim a Gdańskiem. Przytoczony fragment służy jedynie ilustracji doświadczenia egzystencjalnego, które dla osób przybywających zarówno do Gdańska, jak i na Pomorze Zachodnie mogło być podobne. 
funkcjonowanie w tych dwóch systemach relacjonuje młoda bohaterka Homunculusa z tryptyku: „Mama pracuje w »Polonii«. [...]) Ten sam dom nazywał się dawniej »Belwedere« i tej nazwy używa się naturalnie w domu. Dlaczego one [matka i ciotki] nie chcą się do niczego przyzwyczaić? Wszystko było dawniej, naówczas, ponoć lepsze. Nie pamiętam. Mama twierdzi, że powinnam, że muszę jej wierzyć. [...] Ulice znam również podwójnie: na użytek domowy i zewnętrzny. Czasami w obecności mamy złośliwie się mylę i sprawia mi to uciechę w samym środku mojego ja" (HZT, s. 40-41) ${ }^{25}$.

Matka narratorki konsekwentnie używa dawnych, niemieckich nazw ulic i budynków w Międzyzdrojach - i tego samego wymaga od córki. Dziewczynka funkcjonuje więc w przestrzeni, która jest rozdwojona i inaczej nazywana w domu, a inaczej poza nim. Młoda bohaterka postrzega przywiązanie starszego pokolenia do dawnej terminologii jako zacofanie, co rodzi w niej złość i niechęć. Jest to pobudka do kontestowania tej sytuacji na miarę swoich dziecięcych możliwości, a jednocześnie jedna z przyczyn konfliktów międzypokoleniowych.

Elżbieta Rybicka wyodrębnia trzy metafory oddające relacje między miastem a pamięcią kulturową: palimpsest, ślad i pole walki. Sytuacja przedstawiona w Homunculusie z tryptyku bardzo dobrze ukazuje użyteczność trzeciej z tych przenośni. Definiując ją, badaczka odnosi się do zaproponowanego przez Sławomira Kapralskiego pojęcia krajobrazu pamięci, rozumianego jako ,wielopłaszczyznowy kompleks znaczeń, rozmaicie postrzegany w zależności od usytuowania poszczególnych podmiotów”26. Rybicka dopowiada: „»łkrajobraz pamięci« nie jest $\mathrm{w}$ tym ujęciu tylko terytorium wytwarzania tożsamości, ale w równym stopniu polem walki o władzę symboliczną, krajobrazy mogą bowiem zawierać wiele spornych pamięci. [...] W konsekwencji miasto jako pole walki nie jest nieruchomym obiektem, statyczną przestrzenią, ale dynamicznym członem relacji, ujmowanym perspektywicznie w procesach i praktykach zapominania, wypierania, upamiętniania, a więc zderzania się rozmaitych konfliktowych strategii”’27.

\footnotetext{
${ }^{25}$ Jest to fragment moim zdaniem najbardziej reprezentatywny. Zarówno w Homunculusie z tryptyku, jak i „,Wypędzeniu” po polsku znaleźć ich można więcej. Przykładowo: „Mama pyta, dokąd idziemy. Do »Astorii«. Dawniej to się nazywało »Kaiserhallen«. Wiem. Milczenie" (HZT, s. 157); „I srogie »wypędzenie po polsku« po krótkiej wędrówce z przedmieścia G. do ulicy Klasztornej (dawnej Klosterstrasse) [...] było po prostu anulowane” (WPP s. 32); „Uczestniczyłem bowiem w ogromnej liczbie pogrzebów na wielu cmentarzach, głównie jednak na Cmentarzu Centralnym (dawnym Zentralfriedhof) w G.” (WPP, s. 42).

${ }^{26}$ Rybicka, „Pamięć”, 203.

${ }^{27}$ Tamże.
} 
Interpretacja przestrzeni miasta jako pola walki jest możliwa w Homunculusie z tryptyku na dwóch poziomach. Na poziomie makro to starania Polaków o dostosowanie zastanej w Międzyzdrojach przestrzeni do wartości własnego uniwersum symbolicznego oraz uczynienie z niej reprezentacji swojej etniczności. Na poziomie mikro to walka o toponimię między młodą bohaterką a starszym pokoleniem. Zapytać trzeba: czemu ta walka ma służyć? Co dziewczynka chce osiągnąć, negując nazewnictwo używane przez matkę? Dlaczego sprawa tak - mogłoby się wydawać - błaha jak nazwy budynków i ulic wywołuje wyraźną złość u obu stron sporu?

Nasilenie emocji wyraźnie wskazuje, że istnieje drugie dno tych konfliktów. Pamiętać należy, że pozostając w Międzyzdrojach, starsze pokolenie Niemców doświadczyło izolacji językowej i dyskryminacji na rynku pracy, musiało dostosować się do wytycznych nowej administracji oraz znalazło się na marginesie życia społecznego. Odebrano również i przemianowano ich przestrzenie kultu religijnego ${ }^{28}$. O ile na te trudności niewiele mogli poradzić, przeciwstawienie się toponimicznemu zagarnianiu przestrzeni było w zasięgu ich możliwości. To, co młoda bohaterka postrzega jako życie przeszłością i brak elastyczności, jest w istocie egzekwowaniem jedynego rodzaju władzy, który im pozostał - władzy nad definiowaniem dla siebie przestrzeni, w której żyją, i przywoływanie z pomocą tej toponimii uniwersum symbolicznego uznawanego za swoje. Najprościej rzecz ujmując, to gest oporu - oporu, który nie będzie szeroko rezonował, lecz dla wykonujących go osób jest tożsamościotwórczy.

Badacze kultury podkreślają znaczenie przestrzeni zarówno dla jednostki, jak i wspólnoty. Aleksander Fiut stwierdził: „,najsolidniejszym oparciem dla jednostkowej samoidentyfikacji jest przestrzeń, która stanowi synonim trwałości i ciągłości”29, a Leszek Kołakowski wymienił terytorium jako jeden z kluczowych elementów budujących tożsamość zbiorową narodów: ,[...] aspektem zbiorowej narodowej »osobowości« jest ciało: terytorium, szczególny krajobraz oraz fizyczne artefakty przeobrażające środowisko naturalne" ${ }^{" 30}$. Występowanie

\footnotetext{
${ }^{28}$ Matka bohaterki ubolewa: „Wyobraź sobie, że nasz kościół też jest teraz katolicki. Kto by to pomyślał?” (HZT, s. 96). Główna bohaterka stwierdza zaś prostolinijnie: „Kościół jest teraz katolicki i nie wolno mi do niego chodzić" (HZT, s. 25).

${ }^{29}$ Aleksander Fiut, „Pusta tożsamość”, w: Na pograniczach literatury, red. Jarosław Fazan, Krzysztof Zajas (Kraków: Universitas, 2012), 377.

${ }^{30}$ Leszek Kołakowski, „O tożsamości zbiorowej”, tłum. Stefan Amsterdamski, w: Tożsamość w czasach zmiany: rozmowy w Castel Gandolfo, oprac. Krzysztof Michalski (Kraków: Znak, 1995), 50.
} 
w pozycji mniejszości narodowej na obszarze należącym do innej nacji oznacza brak oparcia w przestrzeni, a co za tym idzie, zachwianie tożsamości i utratę reprezentacji dla swojej etniczności. W świetle tych rozpoznań nie dziwi, jak silnie starsi bohaterowie Homunculusa z tryptyku przywiązani są do wyobrażenia o swojej przestrzeni etnicznej, do jej choćby mentalnej reprezentacji, gdy została zarówno funkcjonalnie, jak i symbolicznie przejęta przez Polaków.

Uczenie córki dawnej toponimii to $\mathrm{w}$ istocie zaproszenie jej do niemieckiej przestrzeni etnicznej, próba podzielenia się z nią tym, co uznawane za dom, a także element rozbudowanej edukacji kulturowej, którą odbierała od krewnych. Pozostaje jednak odpowiedź na pytanie: dlaczego wysiłki starszego pokolenia wzbudzają w bohaterce tyle irytacji i skąd bierze się w niej potrzeba sabotażu? W odróżnieniu od reszty rodziny dziewczynka jest dwujęzyczna, dwukulturowa (choć za dominującą należy uznać kulturę polską) i nie pamięta czasów przed nastaniem polskiej administracji. Nie podziela więc sentymentów starszego pokolenia wobec dawnej rzeczywistości, a wręcz boi się ewentualnego powrotu tego, co było, lub wyjazdu do Niemiec ${ }^{31}$.

Opór młodej bohaterki przed przyjęciem perspektywy starszego pokolenia wynika więc z lęku przed zmianą, przed nieznanym, a także - jak sądzę - z niechęci do trwania w skostnieniu, które do niczego jej nie jest potrzebne. W przeciwieństwie do reszty rodziny dziewczynka odnajduje się bowiem w teraźniejszości. Przyjęcie i zaakceptowanie podtrzymywanej w domu perspektywy przestrzennej izolowałoby ją i ograniczało, zmuszało do funkcjonowania w świecie wyobrażeń i w poczuciu resentymentu. Jej odmowa przyjęcia dawnej niemieckiej terminologii to ucieczka ku życiu.

\section{Podsumowanie}

Bohaterka Homunculusa z tryptyku konsekwentnie aspiruje do polskości mimo niemałych kosztów strategii asymilacyjnej - przede wszystkim utraty oparcia w rodzinie pochodzenia na bardzo wczesnym etapie życia ${ }^{32}$. Niemcy i niemiec-

${ }^{31}$ „- Teraz na pewno już wkrótce się zmieni i wrócą »nasi«. Boże zrób tak, by to się nie stało lub żeby Felek mógł zostać! Obiecuję Stwórcy tydzień wyjątkowej grzeczności; obiecuję na pianinie ćwiczyć, ćwiczyć, ćwiczyć...” (HZT, s. 28); „Nie chcę wyjeżdżać. Ja nie chcę wyjechać. Ja tu zostanę. Wcale nie wiem, kto to są »nasi«. Wiem, kto jest tu” (HZT, s. 42).

${ }^{32} \mathrm{O}$ wojennych zniszczeniach Warszawy bohaterka dowiaduje się ze Świerszczyka, mając około siedmiu lat, co jest podstawą pierwszej poważnej i zakończonej rękoczynami awantury rodzinnej dotyczącej II wojny światowej. Konflikty na tym tle pojawiają się więc zaraz po tym, gdy dla bohaterki rozpoczyna się proces socjalizacji do polskości. 
kość są w powieści konotowane prawie wyłącznie negatywnie, a bohaterka jako licealistka stanowczo odmawia wyjazdu na stałe do Niemiec mimo błagań matki. Jednocześnie sytuacja bohaterki nie rokuje pełnej asymilacji, zważywszy na to, że doświadcza ona różnych form dyskryminacji ze względu na pochodzenie od dzieciństwa aż po dorosłość, bez względu na osiągnięcie natywnej znajomości języka polskiego, odebranie w Polsce wyższego wykształcenia i uzyskanie prestiżowego zawodu.

Dlatego właśnie określam starania postaci jako aspirowanie do polskości, a nie asymilację. Według definicji Ewy Wysockiej strategia asymilacyjna to „głęboka zmiana systemu wartości doprowadzająca do przyjęcia nowej kultury i wtopienia się w społeczeństwo przyjmujące (utrata tożsamości pierwotnej), przekształcanie kodu kulturowego w zależności funkcjonalnej od warunków zewnętrznych, co skutkuje poczuciem przynależności do nowej kultury i bycia jej pełnoprawnym członkiem oraz adekwatnego do tego sposobu traktowania jej przez grupy kultury wchłaniającej" ${ }^{33}$. O ile te słowa dokładnie opisują postawę bohaterki Homunculusa z tryptyku, o tyle jeden warunek nie zostaje spełniony: mimo ustawicznych starań dziewczyna nie zostaje uznana za pełnoprawną członkinię społeczności polskiej i przez wiele osób jest postrzegana jako obca. Doświadczenie wyobcowania terytorialnego pozostawia więc niezatarte piętno i kładzie się cieniem na całym jej życiu.

Piotr Lachmann doświadczenie dorastania w Polsce opisał następująco: „A we mnie rozpoczął się wielostopniowy i niezakończony proces asymilacji i dezasymilacji. Proces »konfliktogenny«, prowadzący do rozstrojów jeżeli nie nerwowych, to żołądkowych albo jednocześnie i jednych, i drugich albo do stanów apatii i wstrzymywania się od jakiejkolwiek decyzji i jakiegokolwiek kroku w stronę którejkolwiek z »opcji«. Czyli kompletne »zawieszenie« między frontami, językami i postawami” (WPP, s. 32). Przeżycia bohaterki utworu Wuttke, choć nie są identyczne, wydają się podobne. Proces asymilowania się w Polsce oddala ją od niemieckości i - dokładnie jak wskazuje Ewa Wysocka - skutkuje utratą pierwotnej tożsamości. Dziewczyna nie tylko nie wykształca przywiązania do niemieckości, lecz także zaczyna ją postrzegać jako wstydliwy stygmat.

\footnotetext{
${ }^{33}$ Ewa Wysocka, ,»My« i »oni« - dlaczego tak trudno być razem? Odpowiedź pedagoga, psychologa i socjologa", w: Migracja, uchodźstwo, wielokulturowość. Zderzenie kultur we wspótczesnym świecie, red. Danuta Lalak (Warszawa: Wydawnictwo Akademickie „Żak”, 2007), 45.
} 
Rezultatem jest wstrząs tożsamości i uwięzienie w fazie liminalnej - pomiędzy dwiema kulturami, bez pełnej przynależności do którejkolwiek z nich ${ }^{34}$.

\section{Bibliografia}

Bagłajewski, Arkadiusz. „Miasto-palimpsest”. W: Miejsce rzeczywiste, miejsce wyobrażone. Studia nad kategoria miejsca w przestrzeni kultury, red. Małgorzata Kitowska-Łysiak, Elżbieta Wolicka, 317-337. Lublin: Towarzystwo Naukowe KUL, 1999.

Chwin, Stefan. Hanemann. Gdańsk: Słowo/obraz terytoria, 1997.

Czerska, Tatiana. „Granice w pamięci. Pisarstwo autobiograficzne kobiet jako forma dyskursu neokolonialnego". W: Historie, społeczeństwa, przestrzenie dialogu. Studia postzależnościowe w perspektywie porównawczej, red. Hanna Gosk, Dorota Kołodziejczyk, 423-436. Kraków: Universitas, 2014.

Duć-Fajfer, Helena. „»Jestem u siebie« - tekstualna opozycja przeciw symbolicznemu wykorzenieniu wpisana w dyskurs mniejszościowy w Polsce". W: Historie, spoteczeństwa, przestrzenie dialogu. Studia postzależnościowe w perspektywie porównawczej, red. Hanna Gosk, Dorota Kołodziejczyk, 449-476. Kraków: Universitas, 2014.

Fiut, Aleksander. „Pusta tożsamość”. W: Na pograniczach literatury, red. Jarosław Fazan, Krzysztof Zajas, 377-384. Kraków: Universitas, 2012.

Gwiazdowska, Małgorzata. „Historyczna zabudowa międzyzdrojskiego kurortu. Dawniej i dzisiaj...”. W: Stoneczne Międzyzdroje. Historia i przyroda, red. Kazimierz Kozłowski, Bogdan Jakuczun, 53-72. Cz. 1. Międzyzdroje: Oficyna Wydawnicza Archiwum Państwowego „Dokument”, 2015.

Heimat. Duden.de. Dostęp 5.09.2019. https://www.duden.de/rechtschreibung/Heimat.

Kołakowski, Leszek. „O tożsamości zbiorowej”. Tłum. Stefan Amsterdamski. W: Tożsamość w czasach zmiany: rozmowy w Castel Gandolfo, oprac. Krzysztof Michalski, 44-55. Kraków: Znak, 1995.

Kozłowski, Kazimierz. „Dlaczego Międzyzdroje, a nie Misdroy. Geneza i istota przemian politycznych i ludnościowych po drugiej wojnie światowej”. W: Słoneczne Międzyzdroje. Historia i przyroda, red. Kazimierz Kozłowski, Bogdan Jakuczun, 11-23. Cz. 1. Międzyzdroje: Oficyna Wydawnicza Archiwum Państwowego „Dokument", 2015.

Krajcewicz, Krystyna. Dwie ojczyzny Britty Wuttke. PolskieRadio.pl. Dostęp 16.07.2019. http://www.polskieradio.pl/80/4198/Artykul/1322288,Dwie-ojczyzny-Britty-Wuttke.

\footnotetext{
${ }^{34}$ Temu zagadnieniu poświęcony jest mój artykuł „Bohater liminalny. O tożsamości na skrzyżowaniu kultur", Tekstualia 4 (2017).
} 
Lachmann, Piotr. „»Wypędzenie« po polsku”. W: tegoż, Wywołane z pamięci, 27-46. Olsztyn: Wspólnota Kulturowa „Borussia”, 1999.

Rokicka, Agata. Moje „w domu” jest tutaj. RadioSzczecin.pl. Dostęp 16.07.2019. http:// radioszczecin.pl/245,496,27122015-moje-w-domu-jest-tutaj.

Ruchniewicz, Małgorzata. „Niemcy”. W: Wysiedlenia, wypędzenia i ucieczki 1939-1959. Atlas ziem Polski, red. Witold Sienkiewicz, Grzegorz Hryciuk, 155-210. Warszawa: Demart, 2008.

Rybicka, Elżbieta. „Pamięć i miasto. Palimpsest vs. pole walki”. Teksty Drugie 5 (2011): 201-211.

Twardochleb, Bogdan. Nastały czasy zupetnie genialne... Opowieść o Międzyzdrojach z Britta Wuttke $w$ roli głównej. TransodraOnline.net. Dostęp 25.07.2019. http:// www.transodra-online.net/pl/node/8095.

Wuttke, Britta. Homunculus z tryptyku. Poznań: Wydawnictwo Poznańskie, 1980.

Wysocka, Ewa. ,»My« i »oni« - dlaczego tak trudno być razem? Odpowiedź pedagoga, psychologa i socjologa". W: Migracja, uchodźstwo, wielokulturowość. Zderzenie kultur we współczesnym świecie, red. Danuta Lalak, 42-62. Warszawa: Wydawnictwo Akademickie ,Żak”, 2007.

\begin{abstract}
Abstrakt
Artykuł bazuje na powieści Homunculus z tryptyku autorstwa pochodzącej z Międzyzdrojów pisarki Britty Wuttke, utworem kontekstowym jest natomiast esej Piotra Lachmanna ,Wypędzenie” po polsku. Główny cel pracy to wskazanie i przedstawienie obecnego w obu tekstach doświadczenia, które nazwane zostaje wyobcowaniem terytorialnym. To sytuacja, gdy podmiot mieszka w swojej miejscowości, częstokroć w tym samym domu czy mieszkaniu, chodzi tymi samymi ulicami, bywa w tych samych budynkach, lecz w jego otoczeniu zmienia się wszystko - administracja, ludność, dominująca narodowość i religia, język urzędowy, nazewnictwo ulic i obiektów architektonicznych, kultura i obyczaje. Najważniejsze zjawiska, których doświadcza bohater wyobcowany terytorialnie, to funkcjonowanie w odniesieniu do dwóch języków i kultur, znalezienie się w pozycji obcego wobec grupy dominującej oraz palimpsestowość przestrzeni. W artykule szczegółowo zanalizowane zostało trzecie z tych zjawisk na przykładzie Międzyzdrojów, które stają się metaforycznym polem walki pomiędzy nowo przybyłymi Polakami a pozostałymi w mieście Niemcami, a także dwoma pokoleniami rodziny przedstawionej w Homunculusie z tryptyku.
\end{abstract}




\title{
Territorial Alienation in Western Pomerania: About Britta Wuttke's Homunculus $Z$ tryptyku in a Comparative Perspective
}

\begin{abstract}
The article is based on the novel Homunculus z tryptyku by Britta Wuttke, a writer hailing from Międzyzdroje, while the comparative piece is Piotr Lachmann's essay "Wypędzenie" po polsku. The main purpose of the paper is pointing to and describing an experience, presented in both literary works, which is named territorial alienation. It is a situation occurring when an individual lives in the same place, often in the same house or apartment, walks the same streets, visits the same buildings, but in their surroundings everything had changed - administration, population, the dominant nationality and religion, official language, names of streets and objects of architecture, culture, and customs. The most significant phenomena experienced by a territorially alienated character are: functioning with reference to two languages and cultures, a position of a stranger in relation to a dominant group, and the palimpsestness of space. The article analyses in detail the third of these phenomena, exemplified by Międzyzdroje, which becomes a metaphoric battlefield between the arrived Poles and the Germans who remained in the town, as well as between two generations of a family depicted in Homunculus z tryptyku.
\end{abstract}

